\title{
EMJH MEDIUM WITH 5-FLUOROURACIL AND NALIDIXIC ACID ASSOCIATED WITH SERIAL DILUTION TECHNIQUE USED TO RECOVER LEPTOSPIRA SPP FROM EXPERIMENTALLY CONTAMINATED BOVINE SEMEN
}

\author{
Fabiana Miraglia $^{1 *}$; Zenaide Maria de Moraes $^{1}$; Priscilla Anne Melville ${ }^{1}$; Ricardo Augusto Dias ${ }^{1}$; \\ Silvio Arruda Vasconcellos ${ }^{1}$ \\ ${ }^{1}$ Departamento de Medicina Veterinária Preventiva e Saúde Animal, Faculdade de Medicina Veterinária e Zootecnia da \\ Universidade de São Paulo, São Paulo, SP, Brasil
}

Submitted: September 12, 2007; Returned to authors for corrections: February 06, 2008; Approved: February 15, 2009.

\begin{abstract}
Bovine semen experimentally contaminated with Leptospira santarosai serovar Guaricura was submitted to the modified EMJH medium with 5-fluorouracil $(300 \mathrm{mg} / \mathrm{L})$ and nalidixic acid $(20 \mathrm{mg} / \mathrm{L})$, named as "selective medium" and using the serial dilution technique, in order to evaluate the percentage of recovery of the added microorganism. The selective EMJH medium was found with higher percentage of recovery of leptospiras and minor losses of samples due to contamination with opportunistic microorganisms than the non-selective EMJH medium: 151/376 (40.0\%) of positive growth; and 38/376 (10.0\%) contamination and 58/376 (15\%) and $129 / 376$ (34.0\%), respectively. These results were statistically significant $(\mathrm{p}<0.0001$; Fisher). Differences were found when the frequencies of positive leptospires recovery have been compared in the serial dilution technique $\left(10^{-1}\right.$ to $\left.10^{-4}\right)$ between the selective and non-selective media at different dilution factors. At $1 / 10^{\text {th }}$ dilution the percentages found were $(0 \%, 0 / 80)$ and $(38 \%, 30 / 80)$, at $1 / 100^{\text {th }}$ dilution, $(3 \%, 2 / 80)$ and $(49 \%, 39 /$ $80)$ and at $1 / 1,000^{\text {th }}$ dilution, $(25 \%, 20 / 80)$ and $(50 \%, 40 / 80)$, respectively. The percentage of recovery of leptospires was found to be directly proportional to the dilution used. The methodology of the serial dilution technique (setting at least three dilutions) and the use of selective EMJH medium have been found to be efficient for the isolation of leptospires from the bovine semen samples.
\end{abstract}

Key-words: Leptospires, Culture media, antimicrobial, isolation, semen

\section{INTRODUCTION}

Leptospires are slow growing organisms having a generation time of approximately 24 hours at $30^{\circ} \mathrm{C}$ and the requirement for a rich medium at neutral $\mathrm{pH}$ predisposes the cultivation of those microorganisms sometimes troublesome, particularly from natural sources (Adler et al., Cousineau \& Mckiel, Hussaini \& Ruby, Johnson \& Rogers) $(1,3,7,8)$.

The isolation of leptospires from animal and human tissues, urine and semen has often been difficult due to the presence of contamination, once strictly aseptic methods of collection are not always possible under field conditions (Hussaini e Ruby) (7).
Schönberg and Schönberg et al. $(17,18)$ observed that the isolation of leptospires from material with high bacterial count is difficult once the fast growth of the opportunists leads to the death of leptospires.

The inclusion of antibiotics in the culture medium, which is used to isolate leptospires and the serial dilution technique had been suggested because these proceedings were found effective for inhibiting the growth of contaminants (Adler et al., Cousineau \& Mckiel, Ellis \& Little, Johnson \& Rogers, Myers, Santa Rosa, Schönberg, Turner) $(1,3,5,8,12,15,16,19)$.

Johnson and Rogers (8) showed that 5-fluorouracil is lethal to various microorganisms, but not to leptospires, in

*Corresponding Author. Mailing address: Faculdade de Medicina Veterinária e Zootecnia, Departamento de Medicina Veterinária Preventiva e Saúde Animal. Lab. de Zoonoses Bacterianas. Av. Prof. Dr. Orlando Marques de Paiva, 87, Cidade Universitária, São Paulo, SP, Cep. 5508-900. E-mail: fmiragli@usp.br 
concentrations of $200-400 \mu \mathrm{g} / \mathrm{mL}$. This substance is widely used as an additional medium, with serial dilutions of inocula, to obtain pure primary culture of isolates, however, some strains of Leptospira, may be inhibited by 5-fluorouracil in primary isolation cultures. Therefore, it is advisable to use batches of medium, in parallel, without this substance (Turner) (19).

Russeal et al. (14) observed that the use of 5-fluorouracil at concentrations of $50-1,000 \mu \mathrm{g} / \mathrm{mL}$, in semi-solid EMJH medium, with the addition of $10 \%$ rabbit serum, did not inhibit the growth of Australis, Canicola and Pomona serovars, when the same was incubated at $30^{\circ} \mathrm{C}$ for seven days.

Myers and Varela-Diaz (12) using the media described by Fletcher (1928) and Ellinghausen and McCullough (1965) with the addition of $200 \mu \mathrm{g} / \mathrm{mL} 5$-fluorouracil, indicated the need to subculture later into an antibiotic containing medium, for total elimination of surviving contaminants.

Ris (13) demonstrated that 5 -fluorouracil had a bacteriostatic effect on leptospires from bovine urine when used in Johnson and Rogers' medium (1964), containing bovine albumin, Tween 80, aminoacids, purine and pyrimidine bases, but not in Fletcher's medium.

Hussaini and Ruby (7) concluded that the incorporation of 5 -fluorouracil at concentrations of $100-150 \mu \mathrm{g} / \mathrm{mL}$ in Korthof's medium was found to be effective in inhibiting Staphylococcus aureus and Escherichia coli without affecting leptospires (Wolffi serovar) growth when cultures were incubated at $30^{\circ} \mathrm{C}$ or at room temperature (from $15^{\circ} \mathrm{C}$ to $22^{\circ} \mathrm{C}$ ). It was concluded that Korthof's medium, containing 5-fluorouracil at these concentrations was a useful selective medium for the isolation of leptospires when incubated at appropriate temperatures.

Adler et al. (1) demonstrated that Hardjo and Pomona serovars growth in semi-solid EMJH medium with bovine albumin and Tween 80 , modified by the addition of actidione $(100 \mathrm{mg} / \mathrm{L})$, bacitracin $(40 \mathrm{mg} / \mathrm{L}), 5$-fluorouracil $(250 \mathrm{mg} / \mathrm{L})$, neomycin sulphate $(2 \mathrm{mg} / \mathrm{L})$, polymyxin $B(0,2 \mathrm{mg} / \mathrm{L})$ and rifampicin $(10 \mathrm{mg} / \mathrm{L})$ would be recommended for inhibiting the oportunistic microorganisms, but these same serovars did not grow in selective EMJH medium enriched with rabbit serum.

Schönberg (17) found that pure cultures of Icterohaemorrhagiae, Canicola, Pomona, Grippotyphosa and Tarassovi serovars, in Korthof' medium with rabbit serum, vancomicin $(10 \mathrm{mg} / \mathrm{L})$ and nalidixic acid $(50 \mathrm{mg} / \mathrm{L})$ produced the lowest adverse effects on the multiplication phase of leptospires.

Schönberg et al. (16) described that the suppressing of contaminants growth for the recovery of leptospires (Icterohaemorrhagiae, Canicola, Pomona, Grippothyphosa, Tarassovi and Hardjo) from swine semen, had been found in EMJH medium with 5-fluorouracil $(100 \mathrm{mg} / \mathrm{L})$ or with the combination of nalidixic acid $(50 \mathrm{mg} / \mathrm{L})$, vancomycin $(10 \mathrm{mg} / \mathrm{L})$ and polymyxin $\mathrm{B}(5000 \mathrm{UI} / \mathrm{L})$. The last combination was better than the 5-fluorouracil, however the need for subcultures was found in a medium free of the inhibitory substances two days after the primary culture.

Freitas et al. (6) described the leptospires isolation of dogs, bovine and swine naturally infected by leptospires. The urine samples from 14 dogs and three bovines and also kidney, liver, ovary and uterus body samples from 36 slaughtered sows with unknown health records were used. The urine and organs samples were cultured in EMJH modified medium, with the addition of $10 \%$ rabbit serum in two formulations, one without antibiotics and the other one with the addition of 5-fluorouracil (400 mg/L), chloramphenicol (5 mg/L), nalidixic acid (50 mg/L), neomycin $(10 \mathrm{mg} / \mathrm{L})$ and vancomycin $(10 \mathrm{mg} / \mathrm{L})$. Incubation was performed at $28^{\circ} \mathrm{C}$ during 24 hours, followed by subculture in modified EMJH medium without antibiotics. Leptospira spp could be isolated from urine samples from $11 \mathrm{dogs}$, two bovines and liver fragments from swines.

The aim of this study was to evaluate the efficacy of EMJH semi-solid and modified medium with 5-fluorouracil and nalidixic acid associated with the serial dilution technique for the isolation of Leptospira santarosai serovar Guaricura from bovine semen experimentally contaminated.

\section{MATERIALAND METHODS}

The Ellinghausen, McCullough, Johnson and Harris - EMJH (Becton-Dickinson Biosciences/DIFCO/Detroit/USA) modified, semi-solid medium was prepared with the addition of $15 \%$ rabbit serum and enriched with L-asparagin (3\%), calcium chloride (1\%), magnesium chloride (1\%), pyruvate sodium ( $1 \%$ ) and $0.2 \%$ agar $^{1}$ $(\mathrm{w} / \mathrm{v})$. This culture medium was prepared in two formulations, one without antibiotics (non-selective) and the other, with the addition of 5 -fluoruracil $^{2}(300 \mathrm{mg} / \mathrm{L})$ and nalidixic $\operatorname{~acid}^{3}(20 \mathrm{mg} / \mathrm{L})$, named as the selective medium (Ellis et al.) (5).

The inoculum was Leptospira santarosai serovar Guaricura, Sejroe serogroup, M04-98 strain, isolated from the urine of buffalo (Buballus bubalis) (Vasconcellos et al.) (20), typed by monoclonal antibodies technique (Terpstra et al. 1985) and cultivated in semi-solid EMJH modified medium (Alves et al., Turner) $(2,19)$.

The concentration of leptospires was adjusted to contain 20 to 30 live spirochetes when observed under the dark field microscopy, with 200x objective (15) and the standard volume of 2,0 mL of leptospires culture with $1,0 \mathrm{~mL}$ of semen diluted in egg yolk-citrate extender. These mixtures were incubated at $28^{\circ}$ to $30^{\circ} \mathrm{C}$ by $30 \mathrm{~min}$., for the contact between the leptospires and the diluted semen. The next step, four ten -fold serial dilutions

\footnotetext{
${ }^{1}$ Bacto-Agar - DIFCO (Detroit USA)

2 5-Fluorouracil - ICN Pharmaceuticals

${ }^{3}$ Nalidixic Acid - SIGMA

${ }^{4}$ DIFCO (Detroit USA)
} 
$\left(10^{-1}\right.$ to $\left.10^{-4}\right)$ were performed in modified EMJH, without agar and antibiotics $(2,19)$. Each dilution was cultured in five tubes with selective EMJH in proportion at 1:10 (v/v). After $24 \mathrm{~h}$ incubation at $28^{\circ}$ to $30^{\circ} \mathrm{C}$, these dilutions were sub cultured in the same proportion in EMJH, without antibiotics, and then incubated at $28^{\circ}$ to $30^{\circ} \mathrm{C}$ for six weeks. Eight repetitions were carried out. Cultures were examined weekly under dark field microscopy and tubes showing contaminants were discarded. The control of microorganims in semen was carried out by cultivation in appropriate culture media. Seven frozen semen samples and a fresh one (from each repetition) were cultivated in $\mathrm{BHI}^{4}$ (brain heart infusion) broth and after $24 \mathrm{~h}$ at $37^{\circ} \mathrm{C}$, they were cultivated in 5\% sheep blood agar, MacConkey agar and Saboraud-dextrose agar. Blood and MacConkey agar plates were incubated at $37^{\circ} \mathrm{C}, 24$ to $72 \mathrm{~h}$. Saboraud plates were kept at room temperature for at least seven days. Microorganisms that were isolated have been identified by macro and microscopically and by biochemical characteristics, and were classified according to Krieg and Holt Murray et al. $(9,10)$.

\section{RESULTS AND DISCUSSION}

In Table 1, there are significant differences shown ( $p<0.0001$; Fisher) in the percentage of recovery of leptospires by cultivation, under selective EMJH medium, with $40 \%$ growth of leptospires (151/376) and non-selective EMJH with $15 \%$ growth of leptospires (58/376). Significant differences $(p<0.0001$; Fisher) were found in the percentage of contamination by microorganisms, 10,0\% (38/376) of samples from selective EMJH medium were contaminated and 34,0\% (129/376) of samples from non-selective EMJH medium. These results were according to Adler et al., Cousineau \& Mckiel, Hussaini \& Ruby, Johnson and Rogers, Schönberg et al. (1981) and Schönberg (1980) $(1,3,7,816,17)$ who observed that the isolation of leptospires from material with high bacterial count was difficult, once the fast growth of the contaminant microorganisms led to leptospires death.

In Table 2, there are illustrated the results of bacterial cultures from semen with eight repetitions. Six out of seven samples of frozen semen presented growth of Corynebacterium $s p(6 / 7)$, four of Bacillus sp (4/7), two of Streptococcus sp (2/7) and one of Micrococcus $s p(1 / 7)$, suggesting that microorganisms present in the environment affected the samples preparation, because from the fresh semen sample, only Proteus mirabilis (1/1) was isolated. There was no growth of molds and yeasts. The antibiotics, at the concentrations used in the EMJH medium, were found to be able in inhibiting contaminants but not leptospires. Myers and Varela-Diaz (12) found that subcultures were needed further on into an antibiotic containing medium, for total elimination of surviving contaminants after $24 \mathrm{~h}$, differently from what was described by Freitas et al., Turner, and Schönberg et al $(6,16,19)$, that sub cultured after two days.
Table 1. Number of samples with positive leptospires cultures* and contaminated cultures according to the type of EMJH medium used.

\begin{tabular}{lccc}
\hline Culture Medium & Positives & Contaminated & TOTAL \\
\hline $\begin{array}{l}\text { EMJH } \\
\text { (non-selective) }\end{array}$ & $58(15.0 \%)^{\mathrm{a}}$ & $129(34.0 \%)^{\mathrm{a}}$ & $187(50.0 \%)$ \\
EMJH(selective) & $151(40.0 \%)^{\mathrm{b}}$ & $38(10.0 \%)^{\mathrm{b}}$ & $189(50.0 \%)$ \\
TOTAL & $209(56.0 \%)$ & $167(44.0 \%)$ & $376(100.0 \%)$ \\
\hline
\end{tabular}

* incubation at $28^{\circ}-30^{\circ} \mathrm{C}$ and assessed weekly for up to six weeks through dark field examination; a, b: different superscripts, in the same column, significant difference; FISHER: $p<0.0001$.

Table 2. Microorganisms other than leptospires isolated from semen samples in each repetition.

\begin{tabular}{cc}
\hline Repetition & Isolated Microorganisms \\
\hline $01^{(1)}$ & Corynebacterium $s p$ \\
$02^{(1)}$ & Corynebacterium $s p /$ Streptococcus $s p$ \\
$03^{(1)}$ & Bacillus $s p /$ Corynebacterium $s p$ \\
$04^{(1)}$ & Bacillus $s p /$ Corynebacterium $s p$ \\
$05^{(1)}$ & Bacillus $s p /$ Corynebacterium $s p$ \\
$06^{(1)}$ & Bacillus $s p /$ Corynebacterium $s p$ \\
$07^{(1)}$ & Micrococcus sp / Streptococcus $s p$ \\
$08^{(2)}$ & Proteus mirabilis \\
\hline
\end{tabular}

(1) frozen semen (2) fresh semen.

In Table 3, positive and negative cultures to leptospires are shown according to the type of EMJH medium and the serial dilution used. Differences were found between the selective EMJH and the non-selective at the dilutions $10^{-1}, 10^{-2}$ : and $10^{-3}$. The percentage of leptospires recovered was found to be directly proportional to the dilution applied in two media formulations and the growth percentage was higher in selective EMJH at the three dilutions used. These results agree to those of Adler et al., Cousineau \& Mckiel, Ellis \& Little, 1986; Johnson \& Rogers, Myers, Santa Rosa, Schönberg, Turner $(1,3,5,8,11,15,18,19)$ who showed that the incorporation of antibiotics in the culture medium and applied for the isolation of leptospires, using the serial dilution technique, was found to be effective in inhibiting the growth of contaminant microorganisms .

In Fig. 1, it is presented the percentage of growth of leptospires in bovine semen samples, experimentally contaminated with Leptospira santarosai serovar Guaricura and according to the serial dilution and EMJH medium. The selective EMJH was found with high percentages of recovery of leptospires than non-selective EMJH in all of dilutions used. 
Table 3. Number of samples with positive leptospires cultures* according to EMJH medium type and dilution applied.

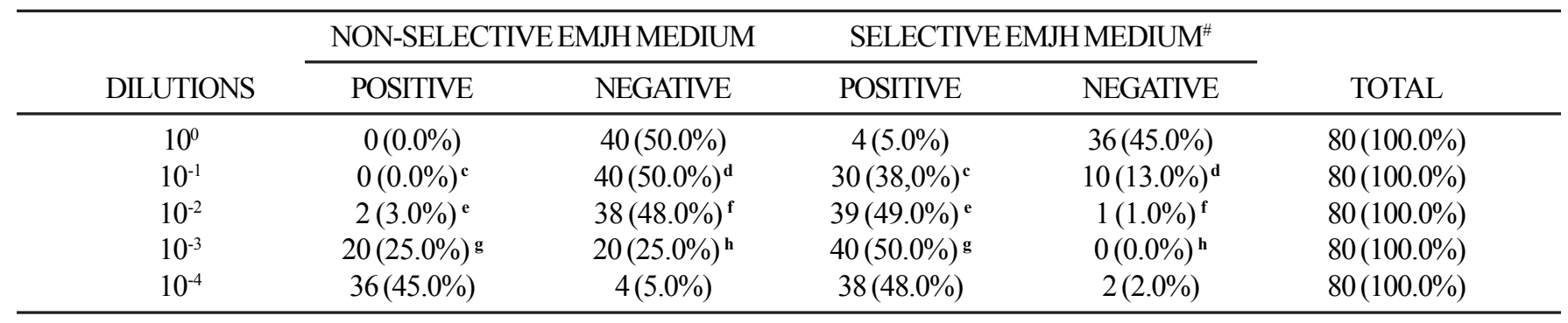

* incubation at $28^{\circ}-30^{\circ} \mathrm{C}$ and assessed weekly for up to six weeks through dark field examination; c, d, e, f, g, h: different superscripts, in the same column, significant difference; ${ }^{\#}$ 5-fluorouracil and nalidixic acid; FISHER: $<<0.0001$.

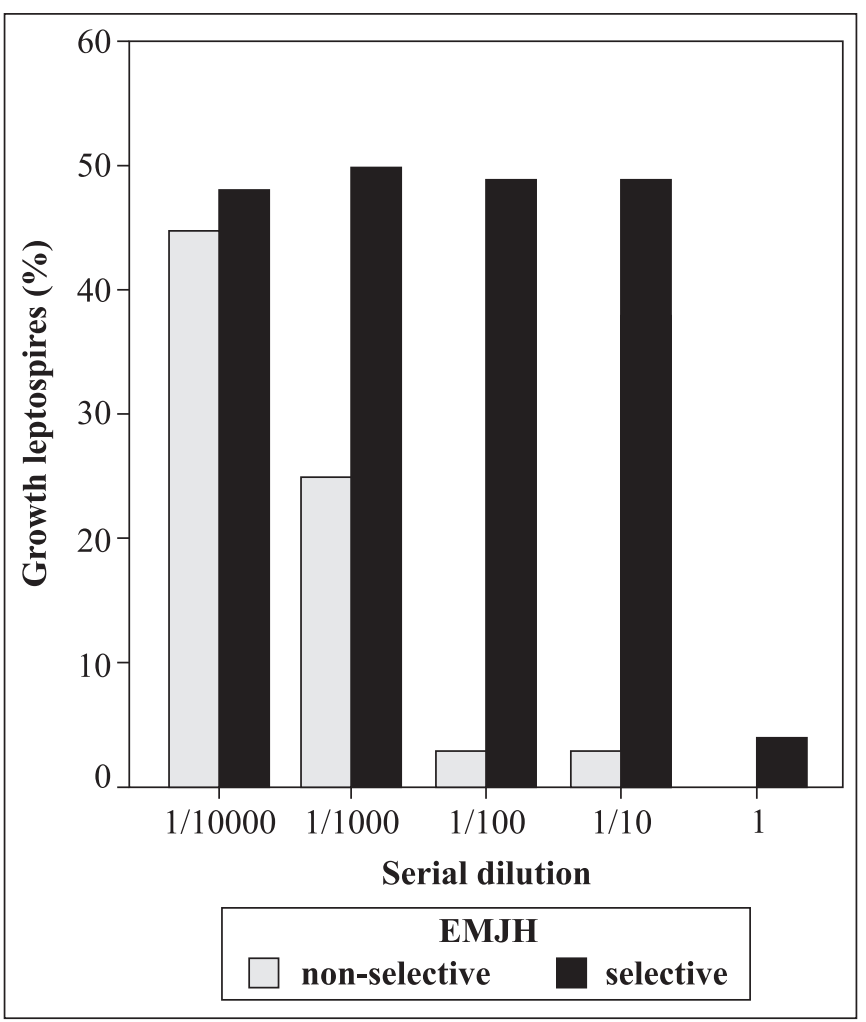

Figure 1. Growth of leptospires (\%) in bovine semen samples, experimentally contaminated with Leptospira santarosai serovar Guaricura, according to the serial dilution using EMJH medium type.

The association of the serial dilution technique (at least three dilutions) with the use of the selective EMJH medium under the test conditions of the experiment were found to be an efficient procedure for the recovery of leptospires from the bovine semen.

\section{RESUMO}

\section{Meio de EMJH com 5-fluorouracil e ácido nalidíxico associado a técnica das diluições seriadas usados para recuperar Leptospira spp do sêmen bovino experimentalmente contaminado}

Sêmen bovino experimentalmente contaminado com a estirpe Leptospira santarosai Sorovar Guaricura foi utilizado para verificar a porcentagem de recuperação de leptospiras, utilizando o meio de EMJH com 5-fluorouracil (300 mg/L) e ácido nalidíxico (20 mg/L), denominado "meio seletivo", associado à técnica das diluições seriadas. O meio seletivo EMJH foi encontrado com porcentagem de recuperação mais elevada e com menos perda de amostras devido à contaminação com microorganismos oportunistas quando comparado com o meio EMJH não seletivo, que foram encontrados, respectivamente, com 151/376 (40.0\%) de crescimento positivo e 38/376 (10.0\%) de contaminação, 58/ $376(15 \%)$ e $129 / 376(34.0 \%)$. Estes resultados foram estatíticamente significantes ( $p<0,0001$; Fisher). Diferenças foram encontradas quando as freqüências de leptospiras recuperadas foram comparadas com a técnica de diluição seriada $\left(10^{-1}\right.$ a $\left.10^{-4}\right)$ e entre os meios seletivo e não-seletivo, em diferentes níveis de diluição. À diluição de 1/10, as porcentagens encontradas foram $(0 \%, 0 / 80)$ e $(38 \%, 30 / 80)$; à diluição $1 / 100,(3 \%, 2 / 80)$ e $(49 \%, 39 /$ $80)$; e à diluição $1 / 1000,(25 \%, 20 / 80)$ e $(50 \%, 40 / 80)$, respectivamente. A porcentagem de recuperação de leptospiras foi diretamente proporcional às diluições empregadas. A metodologia das diluições seriadas (estabelecendo pelo menos três diluições) e o uso de meio EMJH seletivo mostraram ser eficientes no isolamento de leptospiras presentes nas amostras de sêmen bovino.

Palavras-chave: Leptospiras, meio de cultura, antimicrobianos, isolamento, sêmen. 


\section{REFERENCES}

1. Adler, B.; Faine, S.; Christopher, W.L.; Chappel, R.J. (1986) Development of and improved selective medium for isolation of leptospires from clinical material. Vet. Microbiol., 12: 377-81.

2. Alves, C.J.; Vasconcellos, S.A.; Camargo, C.R.A.; Morais, Z.M (1996). Influência de fatores ambientais sobre a proporção de caprinos soro reatores para a leptospirose em cinco centros de criação do Estado da Paraíba, Brasil. Arq. Inst. Biol. (São Paulo), 63: 11-18.

3. Cousineau, J.G.; Mckiel, J.A. (1961). In vitro sensitivity of Leptospira to various antimicrobial agents. Can. J. Microbiol., 7: 751-8.

4. Eaglesome, M.D.; Garcia, M.M. (1992). Microbiological agents associated with bovine genital infections and semen. Part. I. Brucella abortus, Leptospira, Campylobacter foetus and Tritrichomonas foetus. Vet. Bull., 62: 743-744; 751-758.

5. Ellis, W.A.; Little, T.W.A. (1984). The present state of leptospirosis diagnosis and control. The diagnosis of leptospirosis in farm animals. Vet. Res. Lab., Department of Agriculture Stoney Road, 25-31.

6. Freitas, J.C.; Silva, F.G.; Oliveira, R.C.; Delbem, A.C.B.; Muller, E.E.; Alves, L.A.; Teles, P.S. (2004) Isolation of Leptospira spp from dogs, bovine and swine naturally infected. Cien. Rur, Santa Maria, 34: 3, 853-6.

7. Hussaini, S.N.; Ruby, K.R. (1976). Comparative studies on the use of 5 -fluorouracil in two different media as a selective agent for isolation of leptospira. Res. Vet. Sci., 20: 148-50.

8. Johnson, R.C.; Rogers, P. (1964). 5-fluoro-uracil as a selective agent for the growth of Leptospiraceae. J. Bacteriol., 87: 422-26.

9. Krieg, N.R.; Holt, J.C. (1994). Bergey's Manual of Clinical Bacteriology, 9ed., Baltimore: Willians \& Wilkins, 2298p.

10. Murray, P.R.; Baron, E.J.; Pfaller, M.A.; Tenover, F.C.; Yolker, R.H. (1999). Manual of Clinical Microbiology, 7ed., Washington: American Society for Microbiology, 1773p.
11. Myers, D. (1975). Leptospirosis: Manual de métodos para el diagnostico de laboratorio. Buenos Aires: Centro Panamericano de Zoonosis, OPS/OMS, 46p.

12. Myers, D.M.; Varela-Diaz, V.M. (1973). Selective isolation of leptospires from contaminated material by incorporation of neomycin to culture media. Appl. Microbiol., 25: 781-86.

13. Ris, D.R. (1974). Limitations of the use of 5-fluoro-uracil as a selective agent for the isolation of Leptospira. Appl. Microbiol., 27: 270-71.

14. Russeal, C.J.; Rogers, P. (1964). 5-fluorouracil as a selective agent for growth of Leptospirae. J. Bacteriol., 87: 2, 422-26.

15. Santa Rosa, C.A. (1970). Diagnóstico laboratorial das leptospiroses. Vet. Microbiol., 1: 97-109

16. Schönberg, A. (1981). Studies on the effect of antibiotic substances on leptospires and their cultivation from material with a high bacterial count. Zent. Bakt. Parasit. Infekt. Hyg., 249: 400-406.

17. Schönberg, A.; Kämpe, U.; Rohloff, D. (1980). Methods for detection of leptospires in sperm samples of boar. Berl. Múnch. Tierärztl Wochenschr., 93: 166-171.

18. Terpstra, W.J.; Korver, H.; Van Leeuwen; Klatser, P.R.; Kolk, A.H. (1985). The classification of Sejroe group serovars of Leptospira interrogans with monoclonal antibodies. Zbl. Bakt. Hyg. A 259: 498-506.

19. Turner, L.H. (1970). Leptospirosis III. Maintenance, isolation and demonstration of leptospires. Trans. Royal Soc. Trop. Med. Hyg., 64: 623-646.

20. Vasconcellos, S.A.; Oliveira, J.C.F.; Morais, Z.M.; Baruselli, P.S.; Amaral, R.; Pinheiro, S.; Ferreira, F.; Ferreira-Neto, J.S.; Schönberg, A.; Hartskeerl, R.A. (2001). Isolation of Leptospira santarosai, serovar guaricura from buffaloes (Bubalus bubalis) in Vale do Ribeira, São Paulo, Brazil. Brazil. J. Microbiol., 32: 298-300. 